\title{
Retningslinje for rehabilitering etter ervervet overekstremitetsamputasjon
}

\author{
Norges første retningslinje for rehabilitering av pasienter med ervervet overekstremitetsamputasjon er \\ nå tilgjengelig på nett. Retningslinjen dekker hele rehabiliteringsforløpet. Mange av anbefalingene er også \\ relevante for pasienter med medfødte mangler på overekstremitetene (dysmeli) og for behandling av amputa- \\ sjonsrelaterte smerter hos benamputerte.
}

Personer med ervervet overekstremitetsamputasjon (arm-, hånd/delhånd- og fingeramputasjon) er en pasientgruppe som til nå har hatt et mangelfullt rehabiliteringstilbud i Norge. Det er avdekket store variasjoner i rehabiliteringen og et udekket behov for flere ulike tjenester i kommune- og spesialisthelsetjenesten (1).

Pasientene er i hovedsak unge og ellers friske (2). Amputasjonen påvirker fysisk funksjon, bevegelsesmønster, utseende, arbeidsevne og livskvalitet (1). Gjenopprettelse av optimal funksjon og forebygging av sekundære plager som muskelskjelettsmerter forutsetter tilgang til spesialisert, tverrfaglig rehabilitering. Det kreves også god samhandling mellom spesialisert rehabilitering og andre helsetjenester i førsteog annenlinjetjenesten (som ortopedi og smerteklinikk). Overekstremitetsamputerte har normale livsutsikter, og deres behov endres ofte $\mathrm{i}$ tråd med ulike ervervsmessige og familiære forpliktelser. Dette er dermed en gruppe som har behov for oppfølging i et livsløpsperspektiv $(3,4)$.

Derfor er det nå utarbeidet en kunnskapsbasert faglig retningslinje for rehabilitering etter ervervet overekstremitetsamputasjon i Norge (5). Målet er å sikre denne pasientgruppen enhetlig rehabilitering i tråd med beste praksis og redusere uønsket variasjon i rehabiliteringstilbudet.

\section{Arbeidsgruppen}

Retningslinjen er utarbeidet av en tverrfaglig sammensatt arbeidsgruppe bestående av representanter fra alle landets fem spesialiserte tverrfaglige armamputasjonsteam, de to ortopediske verkstedene i Norge som lager armproteser (Norsk Teknisk Ortopedi og Sophies Minde Ortopedi), primærhelsetjenesten og pasientgruppen. I tillegg bidro en aktiv referansegruppe bestående av helsepersonell med ulik fagbakgrunn knyttet til både primær- og spesialisthelsetjenesten.

Arbeidet ble finansiert av Helsedirektoratet via tilskuddsmidler (på initiativ fra en av forfatterne av denne artikkelen, K. Østlie) og har fulgt Helsedirektoratets Veileder for utarbeidelse av kunnskapsbaserte retningslinjer samt AGREE II (Appraisal of Guidelines REsearch \& Evaluation), et verktøy for utvikling av retningslinjer med vekt på en transparent prosess (6). Litteratur og anbefalinger er kvalitetsvurdert og gradert ved bruk av GRADE (Grading of Recommendations Assessment, Development and Evaluation) (7). Retningslinjen møter dermed standarden for troverdige retningslinjer (8).

\section{Anbefalingene}

Den nye retningslinjen er publisert i den elektroniske retningslinjeplattformen MAGICapp i såkalt topplokkformat (9). Det vil si at man på alle elektroniske plattformer kostnadsfritt kan gå inn og lese dem. Man har også full tilgang til bakgrunnsinformasjon, begrunnelse, nøkkelinformasjon om grunnlagsfaktorer og styrken på hver enkelt anbefaling, oppsummering av tilgjengelig kunnskap og kvaliteten på denne samt eventuell praktisk informasjon.

Styrken på de ulike anbefalingene er basert på en balansert vurdering av kvaliteten på kunnskapsgrunnlaget, balansen mellom fordeler og ulemper ved et tiltak, pasientens verdier og preferanser og kostnadsvurderinger/ressurshensyn. En sterk anbefaling innebærer at fordelene klart veier opp for ulempene og at nær sagt alle pasienter vil ønske/ bør tilbys den anbefalte intervensjonen. Ved svake anbefalinger er balansen noe mer usikker, og det er forventet større variasjon $\mathrm{i}$ individuelle preferanser (10).

Retningslinjen omfatter hele rehabiliteringsforløpet. Det er spesielt viktig å legge merke til de sterke anbefalingene for henvisning til spesialisert rehabilitering og lav terskel for gjentatte tverrfaglige vurderinger. Nyamputerte anbefales henvist til ett av landets fem spesialiserte armamputasjonsteam senest ved utskrivning fra akuttavdelingen. Barn i og under skolealder anbefales regelmessige kontroller for å fange opp nye behov som følge av vekst og utvikling.

Anbefalingene for behandling av amputasjonsrelaterte smerter er i hovedsak svake, blant annet fordi mye av dokumentasjonen er indirekte (f.eks. forskning på andre typer smerte). Dette gjør det ekstra viktig å gjøre kunnskapsgrunnlaget tilgjengelig for å hjelpe klinikere å fatte beslutninger i samråd med pasientene. Det betyr imidlertid også at anbefalingene i hovedsak er relevante og gyldige også for pasienter med benamputasjoner og amputasjonsrelaterte smerter.

\section{Kristin Østlie}

kristin.ostlie@sykehuset-innlandet.no

Lars-Petter Granan
Kristin Østlie (f. 1973) er ph.d., spesialist i fysikalsk medisin og rehabilitering og seksjonsoverlege ved Sykehuset Innlandet HF, Avdeling for fysikalsk medisin og rehabilitering, Otte-

stad.

Forfatter har fylt ut ICMJE-skjemaet og oppgir ingen interessekonflikter.

Lars-Petter Granan (f. 1977) er ph.d.og konstituert overlege ved Avdeling for smertebehandling, Oslo universitetssykehus.

Forfatter har fylt ut ICMJE-skjemaet og oppgir ingen interessekonflikter.

\section{Litteratur}

1. Østlie K. Adult acquired major upper-limb amputees in Norway: prevalence, function and rehabilitation. A population-based survey. Doktoravhandling. Oslo: Unipub, 2012

2. Østlie K, Skjeldal OH, Garfelt B et al. Adult acquired major upper limb amputation in Norway: prevalence, demographic features and amputation specific features. A population-based survey. Disabil Rehabil 2011: 33: 1636-49

3. Esquenazi A. Amputation rehabilitation and prosthetic restoration. From surgery to community reintegration. Disabil Rehabil 2004; 26: 831-6.

4. Meier RH. Evaluation of and Planning for Acquired Upper-Limb Amputee Rehabilitation. I: Atkins DJ، Meyer RH, red. Comprehensive Management of the Upper-Limb Amputee. New York: Springer Verlag, 1989: 16-21

5. Kunnskapsbasert faglig retningslinje for rehabilitering etter ervervet overekstremitetsamputasjon i Norge. www.magicapp.org/public/guideline/ Jn3zaL (5.12.2016)

6. Brouwers MC, Kho ME, Browman GP et al. AGREE II: advancing guideline development, reporting and evaluation in health care. CMAJ 2010; 182: E839-42.

7. Goldet G, Howick J. Understanding GRADE: an introduction. J Evid Based Med 2013; 6: 50-4.

8. Vandvik PO, Berg R, Vist G. En ny generasjon troverdige kliniske retningslinjer. Nor Epidemiol 2013; 23: 197-204.

9. Kristiansen A, Brandt L, Alonso-Coello P et al. Development of a novel, multilayered presentation format for clinical practice guidelines. Chest 2015; 147: 754-63

10. Kristiansen A, Brandt $L$, Berge E et al. Nye retningslinjer for antitrombotisk behandling og tromboseprofylakse. Tidsskr Nor Legeforen 2014; 134: $921-2$.

Mottatt 23.11. 2016, første revisjon innsendt 1.12. 2016, godkjent 5.12. 2016. Redaktør: Ketil Slagstad.

Publisert først på nett. 